57 Official Bulletin of Ukraine, 15 May 2009. No. 33, Article 1139. [In Russian]

58 Official Bulletin of Ukraine, 14 August 2009. No. 59, Article 2071. [In Russian]

5924 October 2012 version, No. 973. Official Bulletin of Ukraine, 6 September 2010. No. 65, Article 2240. [In Russian]

60 Official Bulletin of Ukraine, 30 December 2010. No. 98, Article 3506. [In Ukrainian]

61 VVSU. 2011. No. 26, Article 218. [In Ukrainian]

62 Governmental Courier, 27 July 2011. No. 135. [In Ukrainian]

63 See ORGANIC UA, at http://organic.ua/ru/events/ukevents/. [In Ukrainian]

64 See "News of GMOs", 31 January 2014, at http://www.medsite.com.ua/ gmo_news 460.html. [In Ukrainian]

6511 July 2013, No. 701. Official Bulletin of Ukraine, 11 October 2013, No. 76, Article 2821. [In Ukrainian]

66 See "Biosecurity in Ukraine threatened". Financial News, 5 August 2012, at http://e-finance.com.ua/ru/. [In Ukrainian]
67 See Berezhansky, A. 2012. "GMOs on your table". Contracts 16-17. April 2012. [In Ukrainian]

68 See "Transgenic terror. Part I: Discreet silence of the bourgeoisie, or What the consumer does not even know". Now, 11 December 2007. [In Ukrainian]

69 See Sitnik, Y. 2011. "GMO - Has the horseman of the Apocalypse arrived in Ukraine?" See Ukrhromada.org, 7 January 2011, and http://info.berdyansk.net/ index.php/article/expert/. [In Ukrainian]

70 See "Portal about health and personal growth", at http://zdorovja.com.ua/ content/view/12989/53/. [In Ukrainian]

71 Ibid.

72 VVSU, 2014. No. 40, Article 2021. [In Ukrainian]

73 Ibid., No. 23, Article 873. [In Ukrainian]

74 Ibid., No. 41-42, Article 2024. [In Ukrainian]

75 The proclamation of the territory of Ukraine free of GMOs: the draft law of Ukraine No.476 (registry No.5286-1), at http://www.rada.gov.ua. [In Ukrainian]

\title{
REFERENCES TO OTHER TOPICS
}

\section{Sustainable Soil Management Book}

A new FAO publication, Understanding mountain soils, released in connection with the UN's International Year of Soils, underlines that sustainable soil management is vital for curbing climate change and ensuring food security. Available online: http:// www.fao.org/3/a-i4704e.pdf.

\section{Secretary Ban Urges Immediate Action to Combat Desertification}

On 17 June, in connection with the UN's "Day to Combat Desertification", UN Secretary-General Ban Ki-moon urged the international community to "start securing every hectare of land that can provide food or freshwater and rehabilitate all the degraded land that we can". Press release: http://www.un.org/ apps/news/story.asp?NewsID=51174\#.VcHH3v8w_cs.

\section{Security Council Considers the Implications of Climate Change}

On 30 July, the UN Security Council held an open debate on climate change. A key input into that event was a concept note presented by New Zealand, entitled "Maintenance of international peace and security: peace and security challenges facing small island developing States". UN Document S/2015/543. Available online: http://www.un.org/ga/search/view doc. asp?symbol=S/2015/543.

\section{UN Report: Policy Integration in the Post-2015 Agenda}

The UN Secretary-General has published a report on "Strengthening and building institutions for policy integration in the post-2015 era". Available online: http://www.un.org/ga/ search/view_doc.asp?symbol=E/2015/69.

\section{Record Crowds Expected for Paris Climate \\ Conference}

Registration processes for the upcoming World Climate Conference in Paris have begun. The Secretariat has announced that it will allow 20,000 participants: 10,000 official delegates from the 194 UN Member States, 3,000 media representatives and 7,000 observers. CoP-21 website: http://unfccc.int/meetings/ paris_nov_2015/meeting/8926.php.

\section{UNEP}

\section{- Lending and Investment Tool}

The UN Environment Programme (UNEP) has recently announced the availability of a new online policy tool for financial institutions to assist in reducing deforestation and forest degradation risks. Developed under UNEP's Reducing
Emissions from Deforestation and Forest Degradation (REDD+) programme, the tool is intended "to reduce the deforestation risk caused by the unsustainable production, trade, processing and retail of soft commodities, especially soy, palm oil and beef". Accessible online: http://www.naturalcapitaldeclaration.org/ softcommoditytool/.

\section{- Report on Natural Resources and SDGs}

In a report entitled Policy Coherence of the Sustainable Development Goals, UNEP's International Research Panel warns that "unless prudent natural resource management becomes an integral part of policy packages", the goal of ending extreme poverty by 2030 cannot be met. Prosperity for future and current generations depends on sustainably healthy ecosystems. Full report: http://www.unep.org/resourcepanel/ Portals/50244/publications/Policy_Coherenceofthe_Sustainable_ DevelopmentGoals.pdf.

\section{World Heritage Committee Adds More Biodiversity-rich Sites}

The 39th session of the World Heritage Committee examined a list of 36 possible sites during its meeting in Bonn in June/ July. Following deliberations, UNESCO has added 24 new sites to its World Heritage List, nearly all of which are either listed for natural heritage or combined natural and cultural heritage. The meeting will be covered in more detail in EPL 45(6). In the meantime, IISD's report containing a full and detailed account of these proceedings is available online: http://nr.iisd.org/news/ world-heritage-committee-grants-heritage-status-to-biodiversityrich-sites-in-jamaica-south-africa-viet-nam/.

\section{CITES Reaches 40}

On 1 July 1975, forty years after the Convention on International Trade in Endangered Species of Wild Fauna and Flora (CITES) came into force, its Secretary-General, John Scanlon, reflected on the occasion in a guest article for IISD Reporting Services. Article: http://nr.iisd.org/guest-articles/cites-40-yearsof-international-cooperation-and-national-action/.

\section{Satellite Data Shows Groundwater Depletion}

Data from NASA's GRACE satellite system document that the rate of depletion of Earth's freshwater aquifers is increasing. Twenty of the world's largest aquifers have passed their sustainability tipping points, as more water is being removed than can be replenished under current hydrogeological conditions. News story: http://www.washingtonpost.com/news/wonkblog/ wp/2015/06/16/new-nasa-studies-show-how-the-world-isrunning-out-of-water/. 


\section{Arctic Discussions Planned}

At approximately the same time that this issue reaches the post or website, the GLACIER (Global Leadership in the Arctic: Cooperation, Innovation, Engagement and Resilience) conference, convened by US President Barack Obama, will be on-going in Alaska, scheduled to address several topics related to the Arctic, including how States can collectively address the effects of climate change on the region. Along with President Obama, foreign ministers of Arctic States and key non-Arctic States, as well as scientists, policy makers and stakeholders are expected to attend. Conference announcement and agenda: http://www. state.gov/e/oes/glacier/index.htm.

\section{Decade of African Seas and Oceans}

The African Union has declared 2015-2025 to be the Decade of African Seas and Oceans. Highlighting the 2050 African Integrated Maritime (AIM) Strategy, the launch of this event focused on the need for action on various key elements, including fisheries, aquaculture, and environmental/biodiversity monitoring. AIM Strategy: http://pages.au.int/maritime/documents/2050aim-strategy-0. News story on launch: http://nr.iisd.org/news/ au-launches-decade-of-african-seas-and-oceans/.

\section{African Elephant Census}

In February 2014, 46 scientists began the "Great Elephant Census"; the first pan-African attempt in over 40 years to monitor elephant numbers in national parks across Africa. The effort includes fly-overs covering $600,000 \mathrm{~km}^{2}$ in 20 States, to be completed by the end of 2015. Preliminary results (based on data from about 18 percent of this area) are both sad and encouraging. For example, in Tanzania, 60 percent of the elephant population has fallen to poachers in the last five years, while in Uganda the current count of 5,000 individuals is a marked improvement over the 800 counted during the last census. Census website: http:// www.greatelephantcensus.com/.

\section{EU Resolves to Promote Closed-loop Recycling}

After a single reading, the EU Parliament has resolved to adopt an ambitious text in support of increased efforts to promote closed-loop recycling. The text as approved specifies a higher recycling quota and stresses that a 30 percent increase in resource efficiency could lead to a one percent boost in GDP with the potential to create two million new and more sustainable jobs. "European Parliament resolution of 9 July 2015 on resource efficiency: moving towards a circular economy". (T8-0266/2015). Available online: http://www.europarl. europa.eu/sides/getDoc.do?type=TA\&reference=P8-TA-20150266\&format $=X M L \&$ language $=E N$.

\section{Australian Court Halts Carmichael Coal Mine}

A court in Australia has overturned the government's approval for a giant open-pit coal mine in Queensland, based on its conclusion that the Minister for the Environment had failed to heed evidence presented regarding potential threats to vulnerable animal species. The court acted on a claim filed by the Mackay Conservation Group, noting possible threats to particular species and to the Great Barrier Reef (the mining company had also received permission to build a coal port terminal to facilitate product transportation). The mining company's application will be reconsidered $a b$ initio by the environment ministry, and could be reissued in 6-8 weeks, if the minister so decides. News report: http://www.bbc.com/news/world-australia-33783020.

[NDE, TRY]

\section{Russia Submits Revised Claim on Extension of its Continental Shelf}

The UN Commission on the Limits of the Continental Shelf has received a submission from the Russian Federation revising its 2001 claim for an extension of its continental shelf beyond the EEZ into the Arctic Ocean. Available online: http://www.un.org/ depts/los/clcs_new/submissions_files/submission_rus_rev1.htm.

\section{EU: State of Nature}

EU Member States are required to report to the Commission every six years on the state of species protected under the Habitats Directive. 17,000 data sets have been compiled into the most recent report covering the years 2007-2012. See http://eurlex.europa.eu/legal-content/EN/TXT/?uri=COM:2015:219:FIN.

\section{Islam and Climate}

The "Islamic Declaration on Global Climate Change" presents a moral case, for the world's 1.6 billion Muslims and people of all faiths, to take an active role in combating climate change. Declaration: http://islamicclimatedeclaration.org/islamicdeclaration-on-global-climate-change/.

\section{Sustainable Use of Marine Biological Diversity}

The UN General Assembly has adopted a resolution, without vote, entitled "Development of an internationally legally-binding instrument under the UN Convention on the Law of the Sea on the conservation and sustainable use of marine biological diversity in areas beyond national jurisdiction" (A/Res/69/292). Online at: http://www.un.org/en/ga/search/view_doc.asp?symbol=A/ RES/69/292.

\section{Rise of Sea Levels}

According to NASA, it is inevitable that sea levels will rise over a metre in the next 100-200 years. The loss of glaciers and ice will further accelerate; putting island States and coastal cities at risk. At: http://www.sciencetimes.com/articles/7309/20150909/ sea-level-will-rise-one-meter-over-next-100-years.htm.

\section{Fisheries}

According to a new study, both biological diversity and the amount of fishing by-catch in the North Atlantic increase the deeper the water is. Thus, the damage to ecosystems is higher and economic gain significantly lower at depths below $600 \mathrm{~m}$. The EU may now push through a ban on deep-sea fishing. Article: http://www.nature.com/news/evidence-supports-trawling-depthlimit-1.18254.

[Except as noted, all references NAE] 